\title{
ANALISIS DAYA DUKUNG TIANG AKSIAL TUNGGAL DENGAN METODE STATIS DAN DINAMIS TERHADAP HASIL UJI PILE DRIVING ANALYZE (PDA) PADA PEKERJAAN PONDASI PROYEK JAKARTA BOX TOWER
}

\author{
Evi Puspita Sari ${ }^{1}$, Prihantono ${ }^{2}$, dan Sittati Musalamah ${ }^{3}$ \\ 1,2,3Pendidikan Teknik Bangunan, FT, UNJ \\ Email: evi.puspitasari29@gmail.com
}

\begin{abstract}
ABSTRAK
Tujuan dari penelitian ini adalah untuk mengetahui perbandingan kapasitas bantalan tiang dengan beberapa metode perhitungan statik dan dinamis terhadap hasil pengujian dinamik Pile Driving Analyze (PDA). Analisis menggunakan perhitungan statik menggunakan beberapa metode yaitu metode Meyerhoff, Vesic, a Thomlinson, dan a Terzaghi, Peck dan Mesri. Perhitungan konsultan menggunakan metode Reese \& Wright. Daya dukung dinamis menggunakan catatan jacking pile dari hasil pengujian Hydrolic System Pile Driving (HSPD) dan Pile Driving Analyze. Hasil penelitian menunjukkan bahwa metode Reese \& Wright dengan SPT merupakan hasil uji PDA yang paling mendekati dengan persentase 74,72\%; 76.79\% dan 82.83\% untuk jumlah tiang 310, 368 dan 763. Sedangkan hasil perbandingan catatan jacking pile yang paling mendekati PDA adalah pada nomor tiang 638 dengan persentase $82.83 \%$. Hasil penurunan terbesar terjadi pada tiang pancang 310 dan 763 dengan penurunan sebesar 26,3 mm dan 25,9 mm dengan metode $\alpha$ Vesic + Terzaghi, Peck dan Mesri.
\end{abstract}

Kata kunci: Daya Dukung Pondasi, Analisis, Penurunan

\begin{abstract}
The purpose of this research is to know the ratio of bearing pile capacity with some static and dynamic calculation method to Pile Driving Analyze (PDA) dynamic test result. The analysis uses static calculations using several methods namely, Meyerhoff, Vesic, $\alpha$ Thomlinson, and a Terzaghi, Peck and Mesri methods. Consultant calculation using Reese \& Wright method. Dynamic bearing capacity uses jacking pile record from Hydrolic System Pile Driving (HSPD) and Pile Driving Analyze test results. The results showed that Reese \& Wright method with SPT is the most closely approximated PDA test result with percentage 74,72\%; $76.79 \%$ and $82.83 \%$ for number of pile 310, 368 and 763. While the result of comparison of jacking pile record that most approached PDA is on pile number 638 with a percentage of $82.83 \%$. The largest settlement results are at pile number 310 and 763 with a decrease of $26.3 \mathrm{~mm}$ and $25.9 \mathrm{~mm}$ with $\alpha$ Vesic + Terzaghi, Peck and Mesri method.
\end{abstract}

Keywords: bearing capacity of foundation, Pile Driving Analyze, settlement 


\section{PENDAHULUAN}

Pondasi merupakan elemen sangat penting dalam sebuah konstruksi yang tentunya didukung oleh daya dukung tanah, dimana suatu pondasi akan meneruskan beban pada bangunan ke dalam tanah (Fadilah dan Tunafiah, 2018). Daya dukung ijin pondasi tiang merupakan akumulasi dari daya dukung ujung (end bearing) dan daya dukung selimut (friction). Metode untuk menghitung daya dukung aksial pondasi tiang dikelompokan menjadi tiga, yaitu: (a) Metode statik adalah metode untuk menghitung daya dukung dengan menggunakan prinsip-prinsip mekanika tanah klasik menggunakan data parameter tanah berdasarkan hasil uji laboratorium dan uji lapangan; (b) Metode dinamik adalah metode untuk menghitung kapasitas daya dukung pondasi tiang berdasarkan gaya dinamis saat pemancangan atau rambatan gelombang (wave propagation); dan (c) Uji beban skala penuh (static loading test) adalah metode yang paling dapat dipercaya tapi memiliki beberapa kekurangan, yaitu: membutuhkan biaya yang besar; waktu yang relatif lama; bahaya bagi pekerja karena menggunakan tumpukan blok-blok beton pada saat pengujian (Setio dkk, 2000, diacu dalam Coduto, 2001). Menurut Yusti dan Fahriani (2014) pemilihan metode untuk menghitung daya dukung pondasi tiang pancang tergantung dari parameter data tanah yang dipakai.

Pondasi tidak akan lepas kaitannya dengan alam dibawahnya, yaitu tanah. Menurut Sulha dkk (2019) kondisi tanah yang tanah kerasnya terletak pada kedalaman yang sangat dalam dan tidak mampu untuk menahan bebannya pada kedalaman normal dapat diatasi dengan pondasi tiang (file foundation). Menurut
Sulistia dkk (2018) pondasi tiang dapat digunakan untuk mendukung bangunan yang menahan gaya angkat ke atas, terutama pada bangunan-bangunan tingkat yang dipengaruhi oleh beban angin.

Menurut Fathonah dkk (2018) tanah yang baik adalah tanah yang mempunyai daya dukung tanah yang tinggi, namun tidak semua jenis tanah mempunyai daya dukung tanah yang tinggi dipengaruhi oleh letak geografis yang berbeda-beda. Hasil pengujian tanah pada Proyek Jakarta Box Tower menunjukan bahwa tanah pada area proyek masuk kedalam kategori tanah lunak (SE), karena kelunakannya tersebut membuat pekerjaan struktur gedung menjadi terhambat khususnya pekerjaan struktur pondasi dimana telah terjadi redesign atau pendesainan ulang proyek lantaran keadaan tanahnya tersebut. Hal ini sependapat dengan yang dikemukakan oleh Menurut Setiawan dkk (2012) tanah lunak atau tanah lempung memiliki sifat kohesif. Hal ini sependapat dengan yang dikemukakan oleh Kusuma dkk (2016) bahwa lempung terdiri dari butir yang sangat kecil dan menunjukkan sifat plastisitas dan kohesif. Seperti banyak diketahui bahwa tanah lunak seperti lempung ataupun lanau mengandung nilai kohesi yang dapat mempengaruhi nilai daya dukung pondasi.

Pada perhitungan perencanaan pondasi ini, perencana menggunakan metode Reesse \& Wright (1977) dimana dalam perhitungan tersebut menggunakan data parameter tanah dari uji SPT tanpa memperhitungkan nilai kohesi tanah. Maka diperlukan perkuatan data dengan membandingkan berbagai metode daya dukung terhadap suatu data hasil pengujian yang dianggap aktual sehingga pada penelitian ini akan digunakan 
metode perhitungan daya dukung pondasi dengan memperhitungkan nilai kohesi tanah.

Pada penelitian ini akan dilakukan analisis serta membandingkan nilai daya dukung ijin pondasi tiang aksial tunggal dengan metode statis dan dinamis. Metode statis dengan metode Meyerhoff, Vesic, $\alpha$ Thomlinso, dan $\alpha$ terzaghi, Peck dan Mesri serta metode perencana yaitu Reese \& Wright. Sedangkan metode dinamis berdasarkan data pemancangan jacking pile record dan data Pile Driving Analyze (PDA). PDA merupakan sistem yang paling banyak digunakan untuk pengujian beban secara dinamik dan dilaksanakan dengan cara memasang sensor accelerometer dan starin transducer pada permukaan tiang, kemudian memberikan pukulan di kepala tiang (Maizir dkk, 2015). Seluruh nilai daya dukung ijin akan dibandingkan terhadap hasil pengujian PDA dan selanjutnya akan dihitung nilai penurunan pondasi berdasarkan daya dukung ijin pondasi.

\section{METODE PENELITIAN}

\section{Waktu danTempat Penelitian}

Penelitian dilakukan pada bulan Februari 2017 hingga Juli 2017. Lokasi penelitian dalam penelitian ini pada Jalan Kebon Sirih No. 48-50, Gambir, Jakarta Pusat. Adapun titik penelitian adalah Proyek Jakarta Box Tower.

\section{Teknik Pengumpulan Data}

Pengumpulan data dilakukan dengan mengumpulkan data-data yang diperlukan dalam penelitian ini, diantaranya adalah data umum proyek, data penyelidikan tanah baik dilapangan maupun dilaboratorium, data jacking pile record, data perencanaan pondasi, data hasil uji
PDA, dan data lainnya yang menunjang agar terselesaikannya penelitian ini.

Data Parameter Tanah

1. Data Borlog

2. Data Standard Penetration Test

3. Data Material Tiang

a. Tiang pancang yang digunakan adalah tiang beton pracetak produksi PT. JHS System

b. Mutu tiang $=\mathrm{K}-500$

c. Dimensi tiang $=50 \mathrm{~cm}$ X $50 \mathrm{~cm}$

d. Panjang tiang $=19,5 \mathrm{~m}$ dan $46 \mathrm{~m}$

Metode Meyerhoff

Keterangan:

$$
Q_{p}=A_{p} \cdot c_{u} \cdot N_{c} *
$$

$A_{p} \quad=$ luas penampang ujung tiang $\left(\mathrm{m}^{2}\right)$

$N_{c} * \quad=$ faktor kapasitas daya dukung

$c_{u} \quad=$ kohesi undrained pada tanah diujung pondasi tiang $\left(\mathrm{kN} / \mathrm{m}^{2}\right)$

Metode Vesic

Keterangan:

$$
Q_{p}=A p \cdot c_{u} \cdot N_{c} *
$$

$A_{p} \quad=$ luas penampang ujung tiang $\left(\mathrm{m}^{2}\right)$

$N_{c} * \quad=$ faktor kapasitas daya dukung (berdasarkan Irr teori Vesic)

$c_{u} \quad=$ kohesi undrained pada tanah diujung pondasi $\left(\mathrm{kN} / \mathrm{m}^{2}\right)$

Metode $\alpha$ Thomlinson

$$
Q_{s}=\Sigma \alpha c_{u} p \Delta L
$$

Keterangan:

$\alpha \quad=$ nilai adhesi Thomlinson

$\mathrm{cu} \quad=$ nilai kohesi

$\mathrm{p} \quad=$ keliling tiang

$\Delta L \quad=$ tebal lapisan tanah

Metode $\alpha$ Terzaghi, Peck dan Mesri

$$
Q_{s}=\Sigma \alpha c_{u} p \Delta L
$$

Keterangan:

$\alpha \quad=$ nilai adhesi Terzaghi 
Analisis Daya Dukung... (Evi/ hal. 35-45)

$$
\begin{array}{ll}
\mathrm{cu} & =\text { nilai kohesi } \\
\mathrm{p} & =\text { keliling tiang } \\
\Delta L & =\text { tebal lapisan tanah }
\end{array}
$$

Tabel 1. Data Jackin Pile Record

\begin{tabular}{ccccc}
\hline $\begin{array}{c}\text { N } \\
\text { o. } \\
\text { pil } \\
\text { e }\end{array}$ & $\begin{array}{c}\text { Tang } \\
\text { gal }\end{array}$ & $\begin{array}{c}\text { Tekan } \\
\text { an } \\
(\mathbf{M P a})\end{array}$ & $\begin{array}{c}\text { Tekan } \\
\text { an } \\
\text { (Ton) }\end{array}$ & $\begin{array}{c}\text { Kedala } \\
\text { man }(\mathbf{m})\end{array}$ \\
\hline 31 & $16 / 04 /$ & & & \\
0 & 16 & 8 & 180 & 46 \\
63 & $4 / 3 / 20$ & & & \\
8 & 16 & 19 & 418 & 19.5 \\
76 & $16 / 03 /$ & & & \\
3 & 16 & 8 & 180 & 46 \\
\hline
\end{tabular}

\begin{tabular}{|c|c|c|}
\hline 763 & 313.6 & 72.8 \\
\hline $\begin{array}{l}\text { Sumber: } \\
\text { Test Proye }\end{array}$ & $\begin{array}{l}\text { an Pengujian Dina } \\
\text { arta Box Tower }\end{array}$ & $\begin{array}{l}\mathrm{PDA} \\
\end{array}$ \\
\hline
\end{tabular}

Tabel 2. Data Pile Driving Analyze

\begin{tabular}{cccc}
\hline \multirow{2}{*}{$\begin{array}{c}\text { No. } \\
\text { Tiang }\end{array}$} & \multicolumn{3}{c}{$\begin{array}{c}\text { Daya Dukung } \\
\text { Ultimit Tiang (Ton) }\end{array}$} \\
\cline { 2 - 4 } & \multicolumn{3}{c}{ CAPWAP } \\
\hline 310 & 417.7 & 327.5 & 76.2 \\
638 & 403.7 & 219.1 & 198.6 \\
\hline
\end{tabular}

Tabel 3. Kombinasi $Q_{u}$

\section{Daya Dukung Kombinasi}

(Qu)

1. Meyerhoff $+\alpha$ Thomlinson

2. Meyerhoff $+\alpha$ Terzaghi, Peck dan Mesri

3. Vesic $+\alpha$ Thomlinson

4. Vesic $+\alpha$ Terzaghi, Peck dan Mesri

\section{Teknik Analisis Data}

Teknik yang akan digunakan dalam menganalisa penenlitian ini adalah teknik analisis data deskriptif. Analisis data yang dilakukan ditampilkan pada tabel dan grafik. 
Analisis Daya Dukung... (Evi/ hal. 35-45)

HASIL DAN PEMBAHASAN

Tabel 4. Data Tanah dan Nilai Kohesi DB-1

\begin{tabular}{ccccccccc}
\hline $\begin{array}{c}\text { Depth } \\
(\mathbf{m})\end{array}$ & $\mathbf{N}$ & $\begin{array}{c}\boldsymbol{\gamma}_{\mathbf{s a t}} \\
\left(\mathbf{k N} / \mathbf{m}^{\mathbf{3}}\right)\end{array}$ & $\begin{array}{c}\text { Tebal } \\
\mathbf{L} \mathbf{p}(\mathbf{m})\end{array}$ & $\boldsymbol{\sigma}_{\mathbf{v} \mathbf{( i )}}^{\prime}$ & $\boldsymbol{\sigma}_{\mathbf{w}(\mathbf{i})}$ & $\boldsymbol{\sigma}_{\mathbf{v} \mathbf{v}(\mathbf{i})}$ & $\mathbf{N}_{\mathbf{6 0}}$ & $\mathbf{c}_{\mathbf{u}}$ \\
\hline 1.5 & 3 & 15.9 & 1.5 & 23.85 & - & 23.85 & 4 & 26.667 \\
2.0 & 2 & MAT & 0.5 & 31.80 & - & 31.80 & 3 & 20.00 \\
3.0 & 1 & 15.9 & 1.5 & 55.65 & 14.72 & 40.94 & 2 & 13.33 \\
4.5 & 1 & 15.9 & 1.5 & 79.50 & 29.43 & 50.07 & 2 & 13.33 \\
6.0 & 2 & 16 & 1.5 & 103.50 & 44.15 & 59.36 & 3 & 20.00 \\
7.5 & 4 & 16 & 1.5 & 127.50 & 58.86 & 68.64 & 5 & 33.33 \\
9.0 & 2 & 16.1 & 1.5 & 151.65 & 73.58 & 78.08 & 3 & 20.00 \\
10.5 & 6 & 16.2 & 1.5 & 175.95 & 88.29 & 87.66 & 7 & 46.67 \\
12.0 & 7 & 16.2 & 1.5 & 200.25 & 103.01 & 97.25 & 8 & 53.33 \\
13.5 & 10 & 16.3 & 1.5 & 224.70 & 117.72 & 106.98 & 10 & 66.67 \\
15.0 & 18 & 16.3 & 1.5 & 249.15 & 132.44 & 116.72 & 17 & 113.33 \\
16.5 & 19 & 16.5 & 1.5 & 273.90 & 147.15 & 126.75 & 17 & 113.33 \\
18.0 & 17 & 16.5 & 1.5 & 298.65 & 161.87 & 136.79 & 15 & 100.00 \\
19.5 & 2 & 16.1 & 1.5 & 322.80 & 176.58 & 146.22 & 2 & 13.33 \\
21.0 & 2 & 16.1 & 1.5 & 346.95 & 191.30 & 155.66 & 2 & 13.33 \\
22.5 & 3 & 16.1 & 1.5 & 371.10 & 206.01 & 165.09 & 3 & 20.00 \\
24.0 & 9 & 16.3 & 1.5 & 395.55 & 220.73 & 174.83 & 7 & 46.67 \\
25.5 & 7 & 16.3 & 1.5 & 420.00 & 235.44 & 184.56 & 6 & 40.00 \\
27.0 & 6 & 16.3 & 1.5 & 444.45 & 250.16 & 194.30 & 5 & 33.33 \\
28.5 & 6 & 16.3 & 1.5 & 468.90 & 264.87 & 204.03 & 5 & 33.33 \\
30.0 & 4 & 16.3 & 1.5 & 493.35 & 279.59 & 213.77 & 3 & 20.00 \\
31.5 & 12 & 16.4 & 1.5 & 517.95 & 294.30 & 223.65 & 8 & 53.33 \\
33.0 & 26 & 16.8 & 1.5 & 543.15 & 309.02 & 234.14 & 15 & 100.00 \\
39.0 & 50 & 18.3 & 6 & 652.95 & 367.88 & 285.08 & 28 & 186.67 \\
45.0 & 21 & 16.8 & 6 & 753.75 & 426.74 & 327.02 & 11 & 73.33 \\
46.0 & 4 & 16.9 & 1 & 770.65 & 436.55 & 334.11 & 2 & 13.33 \\
52.5 & 21 & 16.9 & 6.5 & 863.60 & 490.50 & 373.10 & 10 & 66.67 \\
60.0 & 19 & 16.6 & 7.5 & 988.10 & 564.08 & 424.03 & 8 & 53.33 \\
\hline & & & & & & & &
\end{tabular}

Tabel 5. Data Tanah dan Nilai Kohesi DB-2

\begin{tabular}{|c|c|c|c|c|c|c|c|c|}
\hline $\begin{array}{c}\text { Depth } \\
\text { (m) }\end{array}$ & $\mathbf{N}$ & $\begin{array}{c}\gamma_{\text {sat }} \\
\left(\mathbf{k N} / \mathbf{m}^{3}\right)\end{array}$ & $\begin{array}{c}\text { Tebal } \\
\text { Lapisan } \\
(\mathbf{m})\end{array}$ & $\sigma_{v(i)}^{\prime}$ & $\sigma_{\mathrm{w}(\mathbf{i})}$ & $\sigma^{\prime} \mathrm{v0}(\mathrm{i})$ & $\mathbf{N}_{60}$ & $\mathbf{c}_{\mathbf{u}}$ \\
\hline 1.5 & 6 & 16.1 & 1.5 & 24.15 & - & 24.15 & 7 & 46.67 \\
\hline 2.0 & 5 & MAT & 0.5 & 32.20 & - & 32.20 & 6 & 40.00 \\
\hline 3.0 & 5 & 16.1 & 1.5 & 56.35 & 14.72 & 41.64 & 6 & 40.00 \\
\hline 4.5 & 2 & 16.1 & 1.5 & 80.50 & 29.43 & 51.07 & 3 & 20.00 \\
\hline 6.0 & 5 & 15.9 & 1.5 & 104.35 & 44.15 & 60.21 & 6 & 40.00 \\
\hline 7.5 & 6 & 16.2 & 1.5 & 128.65 & 58.86 & 69.79 & 7 & 46.67 \\
\hline 9.0 & 7 & 16.2 & 1.5 & 152.95 & 73.58 & 79.38 & 8 & 53.33 \\
\hline 10.5 & 6 & 16.2 & 1.5 & 177.25 & 88.29 & 88.96 & 7 & 46.67 \\
\hline 12.0 & 8 & 16.2 & 1.5 & 201.55 & 103.01 & 98.55 & 9 & 60.00 \\
\hline
\end{tabular}


Analisis Daya Dukung... (Evi/ hal. 35-45)

\begin{tabular}{cccccccc}
\hline 13.5 & 7 & 16.3 & 1.5 & $226.00 \quad 117.72$ & 108.28 & 7 & 46.67 \\
15.0 & 10 & 16.3 & 1.5 & $250.45 \quad 132.44$ & 118.02 & 10 & 66.67 \\
16.5 & 2 & 16.1 & 1.5 & 274.60147 .15 & 127.45 & 2 & 13.33 \\
18.0 & 3 & 16.1 & 1.5 & 298.75161 .87 & 136.89 & 3 & 20.00 \\
19.5 & 4 & 16.1 & 1.5 & 322.90176 .58 & 146.32 & 4 & 26.67 \\
21.0 & 5 & 16.1 & 1.5 & 347.05191 .30 & 155.76 & 4 & 26.59 \\
22.5 & 6 & 16.2 & 1.5 & 371.35206 .01 & 165.34 & 5 & 33.33 \\
24.0 & 7 & 16.2 & 1.5 & 395.65220 .73 & 174.93 & 6 & 40.00 \\
25.5 & 8 & 16.2 & 1.5 & 419.95235 .44 & 184.51 & 6 & 40.00 \\
27.0 & 9 & 16.3 & 1.5 & 444.40250 .16 & 194.25 & 7 & 46.67 \\
28.5 & 6 & 16.3 & 1.5 & 468.85264 .87 & 203.98 & 5 & 33.33 \\
30.0 & 10 & 16.3 & 1.5 & 493.30279 .59 & 213.72 & 7 & 46.67 \\
33.5 & 26 & 16.8 & 3.5 & 552.10313 .92 & 238.18 & 16 & 106.46 \\
43.0 & 32 & 17.2 & 9.5 & 715.50107 .12 & 308.39 & 17 & 113.33 \\
46.0 & 38 & 16.9 & 3 & $766.20+36.55$ & 329.66 & 19 & 126.67 \\
\hline
\end{tabular}

Tabel 6. Data Tanah dan Nilai Kohesi DB-3

\begin{tabular}{|c|c|c|c|c|c|c|c|c|c|}
\hline $\begin{array}{l}\text { Dept } \\
\text { h (m) }\end{array}$ & $\mathbf{N}$ & $\begin{array}{c}\gamma_{\text {sat }} \\
\left(\mathbf{k N} / \mathbf{m}^{3}\right. \\
)\end{array}$ & $\begin{array}{c}\gamma_{w} \\
\left.k \mathbf{N} / \mathbf{m}^{3}\right)\end{array}$ & $\begin{array}{c}\text { Tebal } \\
\text { Lapisa } \\
\text { n (m) }\end{array}$ & $\sigma^{\prime}{ }_{v(i)}$ & $\sigma_{w(i)}$ & $\sigma_{v 0(i)}^{\prime}$ & $\begin{array}{c}\mathrm{N}_{6} \\
0\end{array}$ & $\mathbf{c}_{u}$ \\
\hline 1.5 & 5 & 16.1 & 9.81 & 1.5 & 24.15 & - & 24.15 & 6 & 40.00 \\
\hline 2.0 & 5 & MAT & 9.81 & 0.5 & 32.20 & - & 32.20 & 5 & 33.33 \\
\hline 3.0 & 4 & 16.1 & 9.81 & 1.5 & 56.35 & 14.72 & 41.64 & 5 & 33.33 \\
\hline 4.5 & 3 & 16 & 9.81 & 1.5 & 80.35 & 29.43 & 50.92 & 4 & 26.67 \\
\hline 6.0 & 5 & 16 & 9.81 & 1.5 & 104.35 & 44.15 & 60.21 & 6 & 40.00 \\
\hline 7.5 & 2 & 16.1 & 9.81 & 1.5 & 128.50 & 58.86 & 69.64 & 3 & 20.00 \\
\hline 9.0 & 3 & 16.1 & 9.81 & 1.5 & 152.65 & 73.58 & 79.08 & 4 & 26.67 \\
\hline 10.5 & 5 & 16.2 & 9.81 & 1.5 & 176.95 & 88.29 & 88.66 & 6 & 40.00 \\
\hline 12.0 & 4 & 16.2 & 9.81 & 1.5 & 201.25 & 103.01 & 98.25 & 4 & 26.88 \\
\hline 13.5 & 7 & 16.1 & 9.81 & 1.5 & 225.40 & 117.72 & 107.68 & 7 & 46.67 \\
\hline 15.0 & 6 & 16.1 & 9.81 & 1.5 & 249.55 & 132.44 & 117.12 & 6 & 40.00 \\
\hline 16.5 & 4 & 16.1 & 9.81 & 1.5 & 273.70 & 147.15 & 126.55 & 4 & 26.67 \\
\hline 18.0 & 3 & 16.1 & 9.81 & 1.5 & 297.85 & 161.87 & 135.99 & 3 & 20.00 \\
\hline 19.5 & 5 & 16.1 & 9.81 & 1.5 & 322.00 & 176.58 & 145.42 & 5 & 33.33 \\
\hline 21.0 & 4 & 16.1 & 9.81 & 1.5 & 346.15 & 191.30 & 154.86 & 4 & 26.67 \\
\hline 22.5 & 5 & 16.1 & 9.81 & 1.5 & 370.30 & 206.01 & 164.29 & 4 & 26.67 \\
\hline 24.0 & 19 & 16.6 & 9.81 & 1.5 & 395.20 & 220.73 & 174.48 & 15 & 100.00 \\
\hline 25.5 & 7 & 16.3 & 9.81 & 1.5 & 419.65 & 235.44 & 184.21 & 6 & 40.00 \\
\hline 27.0 & 8 & 16.3 & 9.81 & 1.5 & 444.10 & 250.16 & 193.95 & 6 & 40.00 \\
\hline 28.5 & 12 & 16.4 & 9.81 & 1.5 & 468.70 & 264.87 & 203.83 & 9 & 60.00 \\
\hline 30.0 & 26 & 16.8 & 9.81 & 1.5 & 493.90 & 279.59 & 214.32 & 18 & 120.00 \\
\hline 31.5 & 26 & 16.8 & 9.81 & 1.5 & 519.10 & 294.30 & 224.80 & 17 & 113.33 \\
\hline 38.0 & 50 & 18.3 & 9.81 & 6.5 & 638.05 & 358.07 & 279.99 & 28 & 186.67 \\
\hline 41.0 & 32 & 17.2 & 9.81 & 3 & 689.65 & 387.50 & 302.16 & 17 & 113.33 \\
\hline 44.0 & 21 & 16.8 & 9.81 & 3 & 740.05 & 416.93 & 323.13 & 11 & 73.33 \\
\hline 45.0 & 25 & 16.9 & 9.81 & 1 & 756.95 & 426.74 & 330.22 & 13 & 86.67 \\
\hline
\end{tabular}


Analisis Daya Dukung... (Evi/ hal. 35-45)

Tabel 7. Hasil Perhitungan Daya Dukung Ijin Tiang

\begin{tabular}{|c|c|c|c|c|c|}
\hline $\begin{array}{c}\text { No. } \\
\text { Pile }\end{array}$ & $\begin{array}{c}\text { Reese \& } \\
\text { Wright }\end{array}$ & $\begin{array}{c}\text { Meyerhoff } \\
+\boldsymbol{\alpha} \\
\text { Thomlinson }\end{array}$ & $\begin{array}{c}\text { Meyerhoff }+ \\
\boldsymbol{\alpha} \text { Terzaghi, } \\
\text { Peck dan } \\
\text { Mesri }\end{array}$ & $\begin{array}{c}\text { Vesic }+\boldsymbol{\alpha} \\
\text { Thomlinson }\end{array}$ & $\begin{array}{c}\text { Vesic }+\boldsymbol{\alpha} \\
\text { Terzaghi, } \\
\text { Peck dan } \\
\text { Mesri }\end{array}$ \\
\hline $\mathbf{3 1 0}$ & 155,00 & 166,34 & 124,14 & 167,49 & 125,29 \\
\hline $\mathbf{6 3 8}$ & 155,00 & 34,95 & 35,22 & 35,06 & 35,33 \\
\hline $\mathbf{7 6 3}$ & 155,00 & 148,26 & 123,65 & 150,91 & 126,30 \\
\hline
\end{tabular}

Berdasarkan perhitungan yang telah dilakukan untuk tiang nomor 310, 638 dan 763 didapatkan nilai daya dukung untuk metode Meyerhoff $+\alpha$ Thomlinson sebesar 166,34 ton, 34,95 ton, dan 148,26; metode Meyerhoff $+\alpha$ Terzaghi, Peck dan Mesri sebesar 124,14 ton, 35,22 ton, 123,65 ton; metode Vesic $+\alpha$

Thomlinson yaitu 167,49 ton, 35,06 ton, 150,91 ton; dan untuk metode Vesic $+\alpha$ Terzaghi, Peck dan Mesri yaitu 125,29 ton, 35,33 ton, dan 126,30 ton. Sementara untuk metode Reese \& Wright yang merupakan hasil perhitungan sementara yaitu 155 ton untuk seluruh tiang.

Tabel 8. Hasil Perbandingan Daya Dukung Ijin Tiang N0.310

\begin{tabular}{|c|c|c|c|c|c|c|c|}
\hline \multicolumn{8}{|c|}{ No. Pile 310} \\
\hline$\frac{\stackrel{0}{8}}{\sum^{\frac{0}{0}}}$ & 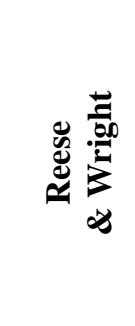 & 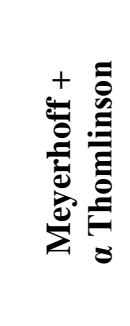 & 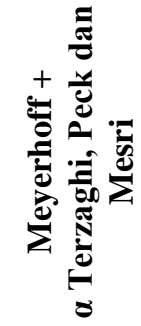 & 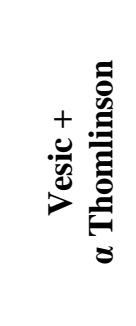 & 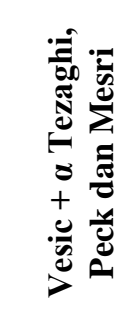 & 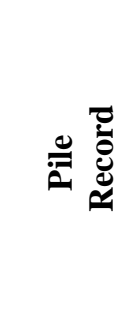 & 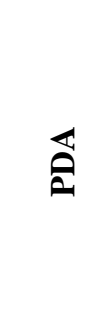 \\
\hline \multirow{2}{*}{$\begin{array}{c}\text { Hasil } \\
(\%)\end{array}$} & 155 & 166.34 & 124.14 & 167.49 & 125.30 & 72 & \multirow{2}{*}{208.85} \\
\hline & $74.22 \%$ & $79.64 \%$ & $59.44 \%$ & $80.20 \%$ & $59.99 \%$ & $34.47 \%$ & \\
\hline
\end{tabular}

Perbandingan daya dukung tiang No.310 terhadap hasil uji PDA (Tabel 8) mendapati bahwa kombinasi metode Vesic dan $\alpha$ Thomlinson sebagai metode yang memiliki rentan persentase paling kecil yaitu $80,20 \%$ dibandingkan dengan metode lainnya yang digunakan dengan hasil dominasi daya dukung selimut (friction). Hal ini sesuai dengan teori yang telah dijelaskan pada Bab 2 dimana untuk tiang yang tertanam tidak mencapai tanah keras maka nilai daya dukung selimut akan jauh lebih besar dibandingkan dengan daya dukung ujung, yakni dengan nilai daya dukung ujung tidak lebih dari 20 ton sedangkan daya dukung selimut hampir mendekati angka 500 ton. Sementara untuk perbandingan daya dukung pile record hanya $34,47 \%$.

Tabel 9. Hasil Perbandingan Daya DUkung IjinTIang No.638

\begin{tabular}{|c|c|c|c|c|c|c|c|c|c|}
\hline \multicolumn{10}{|c|}{ No. Pile 638} \\
\hline 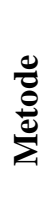 & 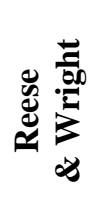 & $\begin{array}{l}+ \\
+ \\
\substack{0 \\
0} \\
\sum_{0}^{0} \\
\sum_{0}^{0}\end{array}$ & ○ & 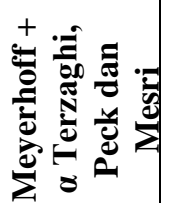 & 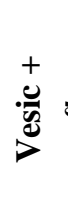 & ช & 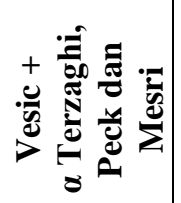 & 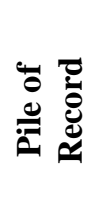 & 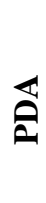 \\
\hline
\end{tabular}


Analisis Daya Dukung... (Evi/ hal. 35-45)

\begin{tabular}{|c|c|c|c|c|c|c|c|}
\hline & & & & & & & \\
\cline { 1 - 7 } $\begin{array}{c}\text { Hasil } \\
(\%)\end{array}$ & 155 & 34.95 & 35.22 & 35.063 & 35.333 & 167.2 & \multirow{2}{*}{201.85} \\
\cline { 2 - 8 } & $\mathbf{7 6 . 7 9 \%}$ & $\mathbf{1 7 . 3 1 \%}$ & $\mathbf{1 7 . 4 5 \%}$ & $\mathbf{1 7 . 3 7 \%}$ & $\mathbf{1 7 . 5 0 \%}$ & $\mathbf{8 2 . 8 3 \%}$ & \\
\hline
\end{tabular}

Metode perhitungan tiang No. 638 yang mendekati hasil uji PDA adalah metode Reese \& Wright dengan nilai persentase 76,79\%. Namun dari keseluruhan data pada titik ini, yang paling mendekati adalah data pile record dengan nilai $82,83 \%$. Hasil perhitungan daya dukung berdasarkan Tabel 4.23 memiliki nilai yang relatif kecil jika dibandingkan dengan tiang lainnya. Hal ini berbanding terbalik dengan data PDA, namun data PDA berbanding lurus dengan data pile record. Perhitugan daya dukung dengan metode statis pada tiang No. 638 memiliki rentan nilai cukup jauh terhadap hasil uji PDA jika dibandingkan dengan tiang No. 310 dan No. 763 dengan menggunakan metode yang sama.
Kemungkinan hal ini dapat terjadi karena adanya kesalahan dalam penginputan data atau karena adanya perbedaan kondisi tanah yang cukup jauh dengan data titik borehole yang digunakan, dimana jarak antara tiang No. 638 berjarak $\pm 10 \mathrm{~m}$ dari titik borehole 3, namun jarak tersebut masih dikatakan aman selama dalam radius $20 \mathrm{~m}-30 \mathrm{~m}$. Alasan adanya perbedaan kondisi tanah dalam jarak yang terbilang cukup aman diperkuat dengan teori yang menyebutkan bahwa karakteristik tanah amat bervariasi dan dapat berubah drastis hanya dalam jarak beberapa meter, sehingga semakin banyak titik penyelidikan tanah maka perencanaan akan menjadi semakin mudah.

Tabel 10. Hasil Perbandingan Daya Dukung Ijin Tiang No.763

\begin{tabular}{|c|c|c|c|c|c|c|c|}
\hline \multicolumn{8}{|c|}{ No. Pile 763} \\
\hline & 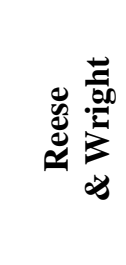 & 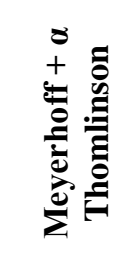 & 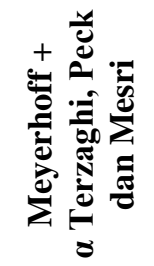 & 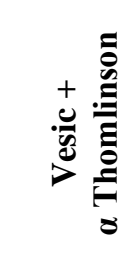 & 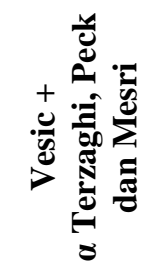 & 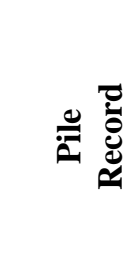 & $\overleftrightarrow{a}$ \\
\hline \multirow{2}{*}{$\begin{array}{c}\text { Hasil } \\
(\%)\end{array}$} & 155 & 148.26 & 123.65 & 150.91 & 126.30 & 72 & \multirow{2}{*}{193.2} \\
\hline & $80.23 \%$ & $76.74 \%$ & $64.00 \%$ & $78.11 \%$ & $65.37 \%$ & $37.26 \%$ & \\
\hline
\end{tabular}

Data hasil perhitungan daya dukung tiang No. 763 menunjukkan bahwa metode perhitungan yang paling mendekati hasil uji PDA adalah metode Reese \& Wright dengan persentase $80,23 \%$. Sama seperti tiang No. 310 dimana kapasitas daya dukung yang dominan adalah daya dukung selimutnya dikarenakan tiang tidak mencapai lapisan tanah keras, sehingga kapasitas daya dukung didominasi oleh nilai tahanan selimut tiang sementara nilai daya dukung ujung jauh dibawahnya. Untuk perbandingan daya dukung pile record dengan PDA memiliki presentase yang cukup kecil, hanya $37,26 \%$.

Tabel 11. Hasil Perhitungan Penurunan Pondasi

\begin{tabular}{|l|l|}
\hline Metode & No. Pile \\
\hline
\end{tabular}




\begin{tabular}{|c|c|c|c|}
\hline & $\mathbf{3 1 0}$ & $\mathbf{6 3 8}$ & $\mathbf{7 6 3}$ \\
\hline $\begin{array}{c}\text { Meyerhoff }+\alpha \\
\text { Thomlinson }\end{array}$ & 22,7 & 15,8 & 21,7 \\
\hline $\begin{array}{c}\text { Meyerhoff }+\alpha \\
\text { Terzagi, Peck } \\
\text { dan Mesri }\end{array}$ & 20,8 & 15,8 & 20,6 \\
\hline $\begin{array}{c}\text { Vesic }+\alpha \\
\text { Thomlinson }\end{array}$ & 26,3 & 16,5 & 25,9 \\
\hline $\begin{array}{c}\text { Vesic }+\alpha \\
\text { Terzaghi, Peck } \\
\text { dan Mesri }\end{array}$ & 24,2 & 16,5 & 24,7 \\
\hline Reese \& Wright & 16,9 & 16,9 & 19,0 \\
\hline
\end{tabular}

a. Hasil perhitungan penurunan tiang No.310 untuk kombinasi metode Meyerhoff $+\alpha$ Thomlinson sebesar 22.7 $\mathrm{mm}$; penurunan Meyerhoff $+\alpha$ Terzaghi, Peck dan Mesri 20.8mm; Vesic $+\alpha$ Thomlinson sebesar 26.3 sedangkan metode Vesic $+\alpha$ mendapatkan penurunan sebesar $24.2 \mathrm{~mm}$.

Gambar 1. Grafik Hubungan Daya Dukung Ijin dan Penurunan Pondasi Tiang 310

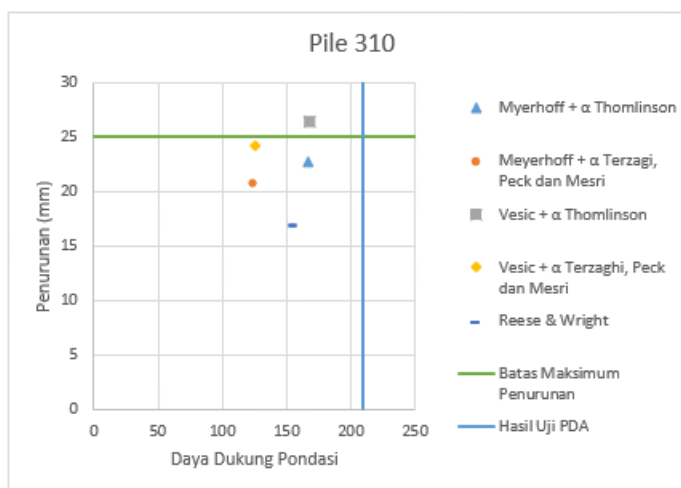

Gambar 2. Grafik Hubungan Daya Dukung Ijin dan Penurunan Pondasi Tiang 638 b. Tabel 11 menunjukkan hasil pnurunan tiang No. 638 relatif kecil jika dibandingkan dengan penurunan tiang No. 310 dan No. 763 dengan nilai 15.8 $\mathrm{mm} ; 15.8 \mathrm{~mm} ; 16.5 \mathrm{~mm}$; dan $16.5 \mathrm{~mm}$ untuk keempat kombinasi metode secara berturut-turut.

c. Hasil penurunan pondasi untuk tiang No. 763 seperti yang ditampilkan pada Tabel 11 dimana kombinasi Vesic $+\alpha$ Thomlinson memiliki nilai terbesar diantara metode yang lainnya dengan nilai penurunan sebesar 25.9; diikuti oleh Vesic $+\alpha$ Terzaghi, Peck dan Mesri sebesar $24.7 \mathrm{~mm} ; 21.7$ metode Meyerhoff $+\alpha$ Thomlinson dan yang terkecil berdasarkan metode Meyerhoff $+\alpha$ Terzaghi, Peck dan Mesri.

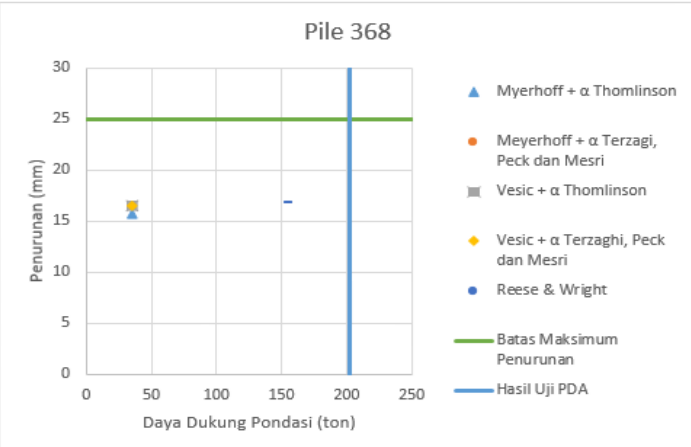

Gambar 3. Grafik Hubungan Daya Dukung Ijin dan Penurunan Pondasi Tiang 763

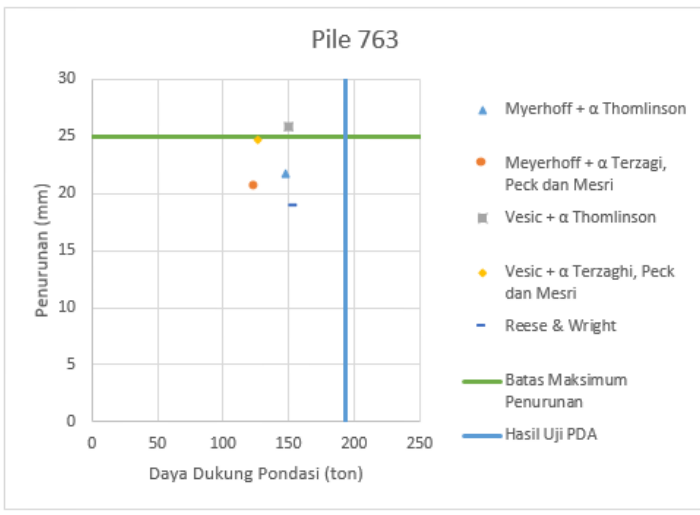


Pengembangan Media Pembelajaran... (Tiara/ hal. 35-45)

Pada Gambar 1, Gambar 2, dan Gambar 3 menunjukkan hubungan antara daya dukung ijin dengan penurunan dari berbagai metode perhitungan yang telah dilakukan. Gambar 4.1 mewakili nilai penurunan serta daya dukung untuk titik 310 , dimana hanya metode Vesic $+\alpha$ Thomlinson yang melebihi batas aman penurunan. Tiang No. 638 dapat dikatakan dalam kondisi aman. Sedangkan tiang 763 sama seperti tiang 310 , terdapat satu metode yang perhitungan penurunannya melebihi batas aman. Penurunan terbesar terdapat pada perhitungan metode Vesic $+\alpha$ Thomlinson, dimana metode ini menghasilkan nilai daya dukung terbesar dari keempat kombinasi metode yang dihitung. Dari tiga titik yang dihitung penurunannya dengan metode tersebut, terdapat dua titik melebihi batas aman yang telah ditentukan, yaitu penurunan < $25 \mathrm{~mm}$. Semakin besar nilai daya dukung pondasi maka semakin besar pula beban yang mampu dipikul oleh pondasi tersebut maka semakin besar penurunan yang terjadi. Hal ini sependapat dengan yang dikemukakan oleh Fahriani and Apriyanti, (2015) bahwa semakin besar beban yang harus ditahan oleh pondasi maka penurunan yang terjadi akan semakin besar.

\section{KESIMPULAN}

1. Metode perhitungan daya dukung yang paling mendekati hasil uji PDA adalah metode Reese \& Wright dengan data NSPT dengan persentase $74,22 \%$, $76,79 \%$, dan $80,23 \%$ nilai tersebut dianggap yang paling konsisten untuk ketiga tiang yang ditinjau.

2. Perbandingan dengan rentan nilai terbesar adalah dengan metode Meyerhoff $+\alpha$ Terzaghi dengan persentase tak lebih dari $65 \%$ pada ketiga tiang yang ditinjau. Nilai daya dukung yang terpaut jauh dengan nilai aktual, dikhawatirkan akan terjadinya kesalahan dalam perencanaan jumlah maupun kedalaman pondasi yang akan dilaksanakan yang akan mempengaruhi terhadap beban yang mampu ditahan tiang serta estimasi biaya struktur pondasi.

3. Metode dinamis dengan data pile record memiliki rentan nilai yang kecil pada titik pile 638 dengan persentase $82,83 \%$. Hal ini dikarenakan tiang tersebut pada saat pemancangan mencapai tanah keras dan daya dukung ujung bekerja hampir sama dengan daya dukung selimut.

4. Penurunan dengan metode Vesic $+\alpha$ Thomlinson memiliki nilai melebihi batas aman yang digunakan, dimana batas aman adalah $<25 \mathrm{~mm}$. Terdapat dua titik tiang melebihi batas penurunan yaitu sebesar $26,3 \mathrm{~mm}$ dan $25,9 \mathrm{~mm}$.

\section{DAFTAR PUSTAKA}

Coduto, Ronald. (2001). Foundation Design Principles and Practices, $2^{\text {nd }}$ Edition.

Fadilah, U. N. and Tunafiah, H. (2018) 'Analisa Daya Dukung Pondasi Bored Pile Berdasarkan Data N-SPT Menurut Rumus Reese\&Wright dan Penurunan', Jurnal IKRA-ITH Teknologi, 2(3).

Fahriani, F. and Apriyanti, Y. (2015) 'Analisis Daya Dukung Tanah dan Penurunan Pondasi Pada Daerah Pesisir 
Pantai Utara Kabupaten Bangka', Jurnal Fropil, 3(2).

Fathonah, W. et al. (2018) 'Pemanfaatan Limbah Plastik PET (Polyethylene Terephthalate) Sebagai Bahan Stabilisasi Tanah Lempung Ekspansif', Jurnal Fondasi, 7(2).

Kusuma, R. I., Mina, E. and Ikhsan, I. (2016) 'Tinjauan Sifat Fisis dan Mekanis Tanah', Jurnal Fondasi, 5(2).

Maizir, H., Jingga, H. and Toni, N. (2015) 'Evaluasi Daya Dukung Tiang Pancang Berdasarkan Metode Dinamik', Annual Civil Engineering Seminar 2015.

Setiawan, A., Supardi and Malawat, W. (2012) 'Perilaku Parameter Kuat Geser dan Kuat Tekan Terhadap Tanah Yang Distabilisasi Dengan Menggunakan Ammonium Chloride', Jurnal Teknik
Sipil, 13(3).

Sulha et al. (2019) 'Analisis Kapasitas Dukung Tiang Pancang Tunggal Berdasarkan Data N-SPT, CPT dan Kalendering', Jurnal STABILITA, 7(1).

Sulistia, A. F., Agustawijaya, D. S. and Tri, S. (2018) 'Analisis Pebandingan Daya Dukung Tanah Pondasi Tiang Pancang Dengan Metode Meyerhoff (Studi Kasus: Proyek Pembangunan Jembatan Panda,Desa Panda Bima (ruas jalan Talabiu - Bima Kabupaten))'.

Yusti, A. and Fahriani, F. (2014) 'Analisis Daya Dukung Pondasi Tiang Pancang Diverifikasi Dengan Hasil Uji Pile Driving Analyzer Test dan Capwap (Studi Kasus Proyek Pembangunan Gedung Kantor Bank Sumsel Babel di Pangkalpinang)', Jurnal Fropil, 2(1). 